\title{
Customers' satisfaction about services quality \& services provided by BASIC bank Ltd. - a study on Khulna
}

\author{
Md. Ariful Islam ${ }^{1}$, Proshenjit Ghosh ${ }^{2}$, Md. Rayhan Islam ${ }^{3}$, Mithun Sarker \\ ${ }^{1}$ BASIC Bank Limited, Khulna, Bangladesh \\ ${ }^{2}$ BRAC Bank Ltd, Dhaka, Bangladesh \\ ${ }^{3}$ Business Administration Discipline, Khulna University, Khulna-9208, Bangladesh
}

Email address:

arifrussell@yahoo.com(Md. A. Islam), proshenjit_ghosh@yahoo.com(P. Ghosh), rayhan_07@yahoo.com(Md. R. Islam), sarker.mithun@ymail.com(M. Sarker)

\section{To cite this article:}

Md. Ariful Islam, Proshenjit Ghosh, Md. Rayhan Islam, Mithun Sarker. Customers' Satisfaction about Services Quality \& Services Provided by BASIC Bank Ltd. - A Study on Khulna. International Journal of Business and Management. Vol. 1, No. 4, 2013, pp. 58-73. doi: 10.11648/j.sjbm.20130104.12

\begin{abstract}
Contemporary business world is very much competitive and the success in the competition is achieved mainly through giving satisfaction to the ultimate consumer. In service oriented industry, it is very difficult to set a standard rule to satisfy customers. Several factors influence customer's decision making to take the service from an organization. The banking industry is a service industry; it provides the customer various financial services. So a banking organization must be keen in identifying the factors which influence their decision in taking the financial service. Thus the bank also needs to know the perception and satisfaction level of the customers about their performance. From the study it is found that significant portion of customers is businessman and private service holder. The customers' satisfaction level towards the overall performance level is quite better. The most positive response factors are products (Average mean value 4.41), procedures of services (average mean score 3.99, charges (average mean score 4.00) and performance of the employee (average mean value 4.11). They are neutral in rate of interest (average mean score 3.67) and physical environment and support (average mean value 3.60). In the last part analysis of the variation in opinion due to demographic difference, it is found that the businessmen are more satisfied by the overall services of BASIC Bank Ltd, Khulna Branch than the service holders. And the customer whose income is between TK. 10000-40000 is more satisfied than the other two groups on average. Moreover, customers whose income is between TK.40000-80000 is less satisfied on average of the six factors. So BASIC Bank Ltd, Khulna Branch need to be concern to remove their dissatisfaction through adopting new mechanism and it will help the bank win customers and increase their profitability.
\end{abstract}

Keywords: Satisfaction, Customer, Banking, Environment, Attitude, Service, Demographic

\section{Introduction}

\subsection{Background of the Study}

Customer service is a buzzword in the contemporary business world. The banking industry is a service industry. It provided its customers various financial services. Thus, a banking organization must be keen in providing quality service to its customers, because banks do their business with the money of their customers. At present, in the banking industry of Bangladesh many renowned banks are operating. Bangladesh is a developing country with per capita national income is US \$ 520. About $42 \%$ people of the country are living under poverty line. Banks and other financial institutions have been playing a key role in activating the financial sectors that in turns infuses dynamism of the country. Actually banks provide necessary funds for executing various programs underway the process of economic development. BASIC Bank limited is one of the specialized banks in Bangladesh. It has given lot money the people of Bangladesh for their economic development.

The aim of learning is to gather practical knowledge from the study. This study is an endeavor to acquire knowledge on corporate environment by engaging in an organization for certain period. This report on 'Customers' Satisfaction about Services Quality \& Services Provided by the BASIC Bank Ltd. - A Study on Khulna" is accomplished in order to gain practical view of customers about their financial service providers. This study is done to know customers' perception 
and evaluation process of products of an organization.

Banks are the financial service providers, producing and selling management of the public funds as well as performing various significant roles in the economy of any country. Globally banking process and its area are spreading faster as well as getting wider day by day. On one hand they are borrowing money from the locals and on the other hand lending the same to the locals. So, people and government are very much depending on these banks as the financial market. In Bangladesh, several private banks are operating their activities since long time. They are playing a vital role in enhancing the quality of the banking service in our country to attract the customer. The BASIC Bank Limited is a forward looking and modern private bank with a long record of sound performance. In this report, a survey study has been to make to analyze the customers' satisfaction on the performance of the bank. This report is expected to have implications for the management of the branch.

\subsection{Objective of the Study}

The study has been conducted to achieve the following objectives:

\subsubsection{Main objective}

The primary objective of the study is to evaluate the customer satisfaction about the services quality \& services provided by BASIC Bank Ltd Khulna Branch.

\subsubsection{Specific Objective}

The specific objective of the study is:

- To explain the services offered to the customers at BASIC Bank Khulna Branch. Along with, the way of the offering the services of the bank will be examined.

- To determine the various customer services expected by customers.

- To recommend to increase the service quality by increasing the dimensions of customer services.

\subsection{Rationality of the Study}

Financial institution or intermediary that mediates or stands between ultimate borrowers and ultimate lenders is known as banking financial institution. Banks perform this function in two ways- taking deposits from various areas in different forms and lending that accumulated amount of money to the potential investors in other different forms. The banking industry is now on growth stage in Bangladesh. Almost in every year new private banks are coming up and new branches of existing banks are also opening up. So, now the industry largely depends upon not only the quantity of services they provide but also the quality of services they render to the customers. All the banks have their own style of operation. Their aim is to attract their target customers by offering them valuable products and better services. These customers choose different banks because of the variety and quality provided services. Customers' satisfaction depends on the products that the banks are offering along with the quality services that the banks are providing. The BASIC
Bank Limited is one of the leading private banks in Bangladesh. All the private banks are offering almost the same categories of products and services to their customers. In this industry many customers are switching their banks due to unsatisfactory services. In an organizational setting, the aim is to achieve the organizational objective that is bringing profit to the organization. As customers are the king in the service oriented industry like bank. So it is very much essential to satisfy their customers through their offering i.e. performance. Therefore, it is very much important to identify the factors which influence the customers to choose their financial institution and their perception on those factors and level of satisfaction in this regard.

\subsection{Methodology of the Study}

\subsubsection{Measuring Service Quality}

The most widely used models in measuring service quality in the banking sector are the SERVQUAL and SERVPERF models. According to the SERVQUAL model (Parasuraman et al., 1988), service quality can be measured by identifying the gaps between customers' expectations of the service to be rendered and their perceptions of the actual performance of the service.

SERVQUAL is based on five dimensions of service quality (Parasuraman et al., 1988):

- Tangibles: The physical surroundings represented by objects (for example, interior design) and subjects (for example, the appearance of employees).

- Reliability: the service provider's ability to provide accurate and dependable services.

- Responsiveness: a firm's willingness to assist its customers by providing fast and efficient service performances.

- Assurance: diverse features that provide confidence to customers (such as the firm's specific service knowledge, polite and trustworthy behavior of employees).

- Empathy: the service firm's readiness to provide each customer with personal

Each dimension is measured by four to five items. Each of these combined 21 items is measured in two ways: the expectations of customers concerning a service and the perceived levels of service actually provided. In making these measurements, respondents asked to indicate their degree of agreement with certain statements on liker type scale. For each item, a gap score $(G)$ is then calculated as the difference between the perception score $(\mathrm{P})$ and the expectation score (E). The greater the gap scores the higher the score for perceived service quality.

The SERVPERF model was carved out of SERVQUAL by Cronin and Taylor in 1992. SERVPERF measures service quality by using the perceptions of customers. Cronin and Taylor argued that only perception was sufficient for measuring service quality and therefore expectations should not be included as suggested by SERVQUAL (Baumann et al, 2007). 
The SERVPERF scale is found to be superior not only as the efficient scale but also more efficient in reducing the number of items to be measured by $50 \%$ (Hartline and Ferrell, 1996; Babakus and Boller, 1992; Bolton and Drew, 1991). In this study, the SERVPERF scale is used to measure to service quality in banking.

\subsubsection{Service Quality and Customer Satisfaction}

Kotler and Armstrong (2012) preach that satisfaction is the pos-purchase evaluation of products or services taking into consideration the expectations. Researchersare divided over the antecedents of service quality andsatisfaction. Whilst some believe service quality leads to satisfaction, others think otherwise (Ting, 2004). The studies of Lee et al.(2000); Gilbert and Veloutsou (2006); Sulieman (2011) and Buttle (1996) suggest service quality leads to customer satisfaction. To achieve a high level of customer satisfaction, most researchers suggest that a high level of service quality should be delivered by the service provider as service quality is normallyconsidered an antecedent of customer satisfaction. As service quality improves, the probability of customersatisfaction increases. Quality was only one of manydimensions on which satisfaction was based; satisfactionwas also one potential influence on future quality perceptions (Clemes, 2008).

Service quality is an important tool to measure customer satisfaction (Hazlina et al., 2011). Empirical studies show that the quality of service offered is related to overall satisfaction of the customer. According toJamal and Anastasiadou (2009), reliability, tangibility and empathy positively related with customer satisfaction. Sulieman (2011) found that reliability, tangibility,responsiveness and assurance have significant and positive relationship with customer satisfaction. Meanwhile empathy was found to have a significant and negative effect on customer satisfaction. Moreover, the result of Ravichandran et al (2010) indicatesresponsiveness is the only significant dimension ofservice quality that affects the satisfaction of customers positively.

\subsubsection{Sources of Information}

The sources of data or information are divided into two parts. Those are primary sources and secondary sources.

\subsubsection{Primary Sources}

In the primary sources, data have been collected from the customers of BASIC Bank Ltd, Khulna Branch.

\subsubsection{Secondary Sources}

In the secondary sources, data have been collected through the different text books and journals relating to the theoretical framework of the study. Furthermore, annual report of the bank and also data collected from the web search.

\subsubsection{Sampling Techniques}

\subsubsection{Population}

The target population for this study is the current consumers of BASIC Bank Ltd, Khulna Branch and total population is 2000 .

\subsubsection{Sample Size}

200 respondents have been taken for this study of the BASIC Bank Ltd among the respondents 115 are current account holders, 70 are savings account holders and rest 15 are cash credit account and short term deposit holders.

\subsubsection{Customer Demographics}

Please note that the figures have been rounded to the nearest decimal place and in some cases, may not ad up to 100 percent.

\begin{tabular}{lcc}
\hline Type of Respondents & Numbers & In percentage \\
\hline Current A/C Holder & 115 & 58 \\
Savings A/C Holder & 70 & 35 \\
CC A/C Holder & 15 & 7 \\
Total & 200 & 100 \\
\hline
\end{tabular}

\subsubsection{Questionnaire Development}

Study instrument is questionnaire and 5 point likert scale is used. The questionnaire consists of both open and close ended questions. Customers' opinions are also taken in some of the cases to identify the reason behind their opinion. The close ended questions were in a 5 points likert scale, (where 5 represents strongly satisfied and 1 represents strongly dissatisfied). Here 27 positive statements have been used to identify the customers' satisfaction on the services of the BASIC Bank Ltd, Khulna Branch. The 27 statements are divided into six broad categories these are products types and features, rate of interest, procedures of services, charges, performance of employees and physical environment and support.

\subsubsection{Data Analysis}

Customers' satisfaction on a particular statement has been determined by calculating mean of the value corresponding to the opinion of the statement. And Standard deviation is used to measure variability of the response among the respondents. Average mean value of the statements under a particular factor is treated as the mean of that factor. Average is calculated to determine the satisfaction of the respondents to a particular factor.

\section{Literature Review}

Marketing has been conceptualized and accepted as an activity directed at satisfying needs and wants through exchange processes. The "Marketing Concept" is essentially the satisfaction of customer needs through integrated marketing with the intent to satisfy the customer while earning a profit. The basic idea is that a satisfied customer will be more likely to repurchase, leading to increased sales and market share for the firm. Integrated marketing activities aimed at producing customer satisfaction include what have been referred to as the "four p's" of marketing, namely 
product, promotion, price, and place. Generally, marketing is considered as the primary functional area in the firm that works to satisfy' the firm's customers. While it is true that customer satisfaction is the result of the total marketing effort, industry has generally failed to recognize the importance of customer service as provided by physical distribution to customer satisfaction and has not effectively integrated customer service with the other components of the marketing mix.' (Journal of Business Logistics. 1994) Customer satisfaction is merely a response to the value proposition offered in specific products/markets (Reidenbach, 1995). By this view, banks must determine how customers define value in order to provide added-value services. Reidenbach (1995) argued that customer value is a more viable element than customer satisfaction because it includes not only the usual benefits that most banks focus on but also a consideration of the price that the customer pays. Customer value is a dynamic that must be managed.

Satisfaction is generally viewed as a broader concept. The customers oriented terms- quality and satisfaction have been the focus of attention alike over the last decades or more. Satisfaction is the consumer's fulfillment response. It is a judgment that a product or service feature, or the product or service itself, provides a pleasurable level of consumption related fulfillment. Customer satisfaction is influenced by specific product or service features and by perceptions of quality .Satisfaction is also influenced by customer emotional response, their attributions, and their perceptions of equity (Zeithamal, V. 1984 pp 85-87). Sureshchandra, G.S., Rajendran, C., and Ananthoraman, R.N. (2002), "the relation between service quality and customer satisfaction- a factor specific approach," Journal of Service Marketing. Bolton and Drew (1991) also proposed that satisfaction leads to service quality.

A previous study found that customer satisfaction is a key and valued outcome of good marketing practice (Fornell 1992; Anderson, Fornell, and Lehmann 1994). According to Drucker (1954), the principle purpose of a business is to create satisfied customers. Increasing customer satisfaction has been found to lead to higher future profitability (Anderson, Fornell, and Lehmann 1994), lower costs related to defective goods and services (Anderson, Fornell, and Rust 1997), increased buyer willingness to pay price premiums, provide referrals, and use more of the product (Reichheld 1996; Anderson and Mittal 2000), and higher levels of customer retention and loyalty (Fornell 1992; Anderson and Sullivan 1993; Bolton 1998). Increasing loyalty, in turn, has been found to lead to increases in future revenue (Fornell 1992; Anderson, Fornell, and Lehmann 1994) and reductions in the cost of future transactions (Reichheld 1996; Srivastava, Shervani, and Fahey 1998). All of this empirical evidence suggests that customer satisfaction is valuable from both a customer goodwill perspective and an organization's financial perspective. Empirical studies have found evidence that improved customer satisfaction need not entail higher costs, in fact, improved customer satisfaction may lower costs due to a reduction in defective goods, product re-work, etc. (Fornell 1992; Anderson, Fornell, and Rust 1997).

Increased customer repurchases increase the profitability of firms (Fornell. 1992) and maintaining customer satisfaction is key to retaining customers (Mittal, Katrichis and Kumar, 2001). Price has been a traditional form of competition but with increased competitive pressures, TQM, instantaneous worldwide communication, and flexible manufacturing, price competition is no longer sufficient. Product design, quality, performance, and delivery have become more important factors in creating customer relationships (Flint, Woodruff and Gardial, 2002). To be competitive, it is important that today's marketers understand exactly which factors drive customer satisfaction judgments and focus on fulfilling those elements. (Journal of the Academy of Business and Economics, 2003)

The most widely accepted model of customer satisfaction is the expectancy disconfirmation paradigm (Patterson, Johnson and Spreng, 1997). In this model, when a consumer's expectation of performance is met, the expectation is said to be confirmed. When actual performance is below the expected level of performance, the expectation is negatively disconfirmed and when actual performance exceeds the expected level of performance, the expectation is positively disconfirmed. Overall satisfaction is considered a multi-attribute model in which overall satisfaction has multiple components. (Journal of the Academy of Business and Economics, 2003)

Early research into satisfaction investigated satisfaction as a uniform construct across all product categories and in all markets. There was an implicit assumption that satisfaction is evaluated in the same way for all types of offerings. As the investigation of customer satisfaction matures, this assumption has begun to be questioned. Yi (1990), in a review of consumer satisfaction, anticipates that satisfaction varies from one product category to another when he questions, "Are the links between the variables different across consumers, products, or situations?" (p. 107). This suggests that the characteristics of an offering influence which aspects buyers use when making satisfaction judgments. For example, satisfaction with office supplies may be driven by satisfaction with the vendor whereas satisfaction with a fork lift may be more influenced by characteristics of the product itself, such as its reliability (Kauffman, 1994).(Journal of the Academy of Business and Economies, 2003)

Mittal, Ross, and Baldasare (1998) find that "a consumer can be both satisfied and dissatisfied with different aspects of the product" (p. 34) at the same time. Thus, a customer might experience overall satisfaction in spite of components that are dissatisfying. Hypothetically, for example, a customer might experience high overall satisfaction because the salesperson was very accommodating and helpful and the vendor shipped on time, even though the product itself was not optimal. This ability to be simultaneously satisfied and dissatisfied with different attributes of the offering is important to marketers; by understanding the relative 
importance of attributes, marketers can spend resources on those attributes that increase levels of overall satisfaction while avoiding expenditures on attributes that have little influence on overall satisfaction (Kellar and Preis, 2003). (Journal of the Academy of Business and Economics, 2003)

In businesses especially in the banking sectors where the underlying products have become commodity-like, quality of service depends heavily on the quality of its personnel. This is well documented in a study by Leeds (1992), who documented that approximately 40 percent of customers switched banks because of what they considered to be poor service. Leeds further argued that nearly three-quarters of the banking customers mentioned teller courtesy as a prime consideration in choosing a bank. The study also showed that increased use of service quality/sales and professional behaviors (such as formal greetings) improved customer satisfaction and reduced customer attrition.

According to Philip Kotler, Bitner, M. J., and Zeithmal, V. A. (2003) added that customer must see service provider as ready and willing to perform.Indeed customer satisfaction has for many years been perceived as key in determining why customers leave or stay with an organization. Organizations need to know how to keep their customers, even if they appear to be satisfied. Reichheld (1996) suggests that unsatisfied customers may choose not to defect, because they do not expect to receive better service elsewhere. Additionally, satisfied customers may look for other providers because they believe they might receive better service elsewhere. However, keeping customers is also dependent on a number of other factors. These include a wider range of product choices, greater convenience, better prices, and enhanced income (Storbacka et al., 1994).

Customer buy goods and services to meet specific needs and they evaluate the outcomes of their purchases based on what they expect to receive .Needs are deeply rooted in people's unconscious and concern long term existence and identity issues. When people feel a need, they are motivated to take action to fulfill it. Customer expectations embrace several different elements, including desired service, adequate service, predicted service and a zone of tolerance that falls between the desired and adequate service levels. Satisfaction can be defined as an attitude - like judgment following a purchase act or a series of consumer- product interactions. Although the terms quality and satisfaction are sometimes used interchangeably, researchers stress the need for greater precision. Customer satisfaction is not and ends in itself. Instead it is the means to achieving a number of key business goals. First, satisfaction is inextricably linked to customer loyalty and relationship commitment. Second, highly satisfied customers spread positive word of mouth and become walking talking advertisements for an organization whose service has pleased them, thus lowering the cost of attracting new customers. Third highly satisfied customers may be more forgiving .Finally delight customers are less susceptible to competitive offerings (Lovelock, 2001, Service Marketing). For example, First Direct, the all telephone bank introduced, has gain huge number a new customers from recommendations by its existing account holders (featured as a case study on pp.639-652, in Lovelock, 2001, Service Marketing).

Though the customers purchase the core product but yet customers are concern about the supplementary elements. Sometimes these supplementary things can enhance or decrease the satisfaction. Customers' satisfaction towards the service includes the core products along with supplementary services (Lovelock, 2001). According to Lovelock supplementary services are two types-facilitating services and enhancing services. Facilitating services includes information, order taking, billing, payment and on the other hand enhancing services includes consultations, hospitability, safe keeping and expectation.

Customers' satisfaction is one of the vital important factors in every organization. There exists a link between the customers' satisfaction and the organization's overall performance. To know the level of customers' satisfaction is essential because it helps the institutions to know how well they are doing in comparison to others and also what the customers' desire from them, what they need to add, removes or change along with core offering. Manager need to be concerned on a day-to-day basis that the customers are satisfied, the operational system are running smoothly and efficiently and the employees are not working productively but are also doing a good jobs either of serving customers directly or helping other employees to deliver good services. However, the distinctive nature of services performances, especially such aspects as involvement in production and the importance of time factors i.e. procedures of services require that some strategic elements be included. To capture the nature of the challenge, 8 Ps model of integrated service can be used, which highlights the strategic decision variables facing managers of service organizations (Lovelock, 2001). According to him these are products elements, place cyberspace and time, process, productivity and quality, people, promotion, education, physical evidence, price and other user costs.

Several studies in the marketing literature have considered the relationship between customer satisfaction and performance at the firm level. Not surprisingly, the results generally show that customer satisfaction provides economic benefits to the firm. For example, customer satisfaction has been linked to increased revenues (Fornell, 1992; Gómez, McLaughlin \& Wittink, 2004; Rust, Zahorik, \& Keiningham, 1995), more inelastic demand (Anderson, 1996), and reduced costs for attracting new customers and other costs associated with poor quality, defects and complaints (Anderson, Fornell, \& Rust, 1997). Reflecting these benefits, customer satisfaction has been found to positively affect a firm's profitability (Anderson, Fornell, \& Lehmann, 1994; Aaker \& Jacobson, 1994; Capon, Farley, \& Hoeni, 1990), and its market value (Aaker \& Jacobson, 1994; Ittner \& Larcker, 1998). While extant literature provides evidence for the positive effect of a firm's customer satisfaction, little if any research has considered the effect of rivals' customer satisfaction on a firm's performance. 
In case of bank, the services are intangible in nature, here the core services is the products and features (deposits and loan) but the supplementary services are the procedure of getting the services, speed of service providing, the physical environment and also the attitude of personnel. As the staff of the organization provide the services so the attitude of the staffs is very important for the customer tom be satisfied when they are getting the service. That's why it is a vital important for every organization to teach their employees about how fairly they will deliver their service. The customers of Nationalized Commercial Banks (NCB) are unsatisfied than that of Private Commercial Banks (PCB). The main reason is that the employees of NCBs do not care to render service to the customer. To provide a quality and satisfactory service, bank needs to identify the reasons customers' preference (F. Ahmed, 1996). According to him there are 6 factors, which affect the customers' preference towards the services of the bank. These are time spent of waiting, cost of service, efficiency of services, and rate of interest, behavior and advice. Along with these factors there are many more elements which affect customers' satisfaction in evaluating the services of the bank.

A previous study in New Zealand banking study found that empathy and assurance are most important for customers' satisfaction (Philip Kotler, Bitner, M. J., and Zeithmal, V. A. (2003)). According to them, empathy means the provision of caring individualized attention to the customer and assurance means that the knowledge and courtesy of employees and their ability to convey trust and confidence. When purchasing services, customers' attention is limited to a small number of tangible inputs (Zeithmal, 1984). Physical environment- buildings, offices and interior design affect customers' beliefs, attitude and satisfaction and provide an opportunity to tell the "right" story about given service (Berry, 1984). It's an important task to make the intangibles into tangible because customers do not usually know what they are getting until they do not get it (Levitt, 1981; 1983) Indeed, the impact of satisfaction on commitment and retention varies in relation to the industry, product or service, environment, etc. However, customer commitment cannot be dependent only on satisfaction (Burnham et al., 2003). Kaynak and Kucukemiroglu's (1992) study of the Hong Kong banking market discovered that customers choose their banks because of convenience, long association, recommendations of friends and relatives, and accessibility to credit.

From the analysis of literature review, some elements can be taken as the indicator of performance measurement criteria of the bank. And these are divided into 6 main factors. The main factors are products, rate of interest, procedure of services, charges, performance of the employees and physical environment and support. These factors affect the customer mostly while they are receiving the service from the bank. The bank needs to identify a customer want and desire to fulfill his or her needs. And customer value is the ratio between the customers' perceived benefits and the resources used.
There are some terms that's defined as follows:

\subsection{Customer Service}

By definition, Customer service refers to the broad range of activates that a company and its employees undertake in order to keep customers satisfied so they will continue doing business with the company and speak positively about the company to other potential customers. (Kotler, 2004)

Customer service is unavoidable. It adds flue to the overall portability of the company. Industrial revolution in the 18th century, growth of individualism, first and second world war, sky-culture and tremendous development of communication technology- all have contributed profoundly to the overall growth of the concept of excellent customer service. All companies whether they manufacture physical goods, such as cars or radios, cigarettes, machineries or provide intangible products such as banking and other financial services offer some type of customer service. Customer service activities can range all the way from providing customers with free parking to letting them transfer funds from their money market accounts. Business that sells physical goods, for example, provide their customers with repair and warranty services, the option to return unsatisfactory' goods, home delivery, telephone ordering lines of credit.

Customer service is a buzzword in the contemporary business word. Most of the companies in the modem world generally use highly sophisticated office equipments and machinery, recruit manpower, use quality raw materials and follows modem management technique but the basic difference lies in providing skillful and quality customer service to its end users. It is actually customer service that differentiates the operational supremacy of difference companies. (Kot1er, 2004).

In 1994 Delta Airlines lost one of the satisfied customers of New York just because of the front desk reception's poor handling of the customer. The lost customer was a chief executive of a renowned company who used to travel all over the world for business reason. It was estimated that Delta Airlines lost US\$ 1.0 million (Havard Business Review Sep-Oct 1995) in the ibrm of ticket value from the particular company during 1994. That is why, customer service is the single most dominant intangible factor that gives company an unprecedented corporate image, solid bandage with customer, higher profitability and win-win situation to the overall business transactions.

Two type of customer services are, External and Internal Customer Service.

\subsection{External Customer Service}

An external customer service is a services which is given to a person or a business who in a position to i) buy or use the company's products and services or ii) advise to buy or use its products and services, for example, doctors or patients for any medicine company.(Zeithaml,1984,A Conceptual Model of Service Quality) 


\subsection{Internal Customer Service}

An internal customer service is a service that is provided b' the employees of a company to other employees of the same company. For example, the services of the employees of accounting, information systems or human resources department to their fellow employees. This service is crucial in helping them meet the needs of company's external customers.(Zeithaml. I 984, A Conceptual Model of Service Quality)

\subsection{Customer Satisfaction}

Satisfaction is a person's feelings of pleasure or disappointment resulting from comparing a product's perceived performance in relation to his or her expectations. If the performance falls short of expectations the customer is dissatisfied. If the performance matches the expectations, the customer is satisfied. If the performance exceeds expectations, the customer is highly satisfied or delighted. (Kotler, 2004)

\subsection{Tools of Measuring Customer Satisfaction}

Measurement of customer satisfaction plays a very vital role in current days. Without satisfying customer needs and wants properly, it might be difficult for the company to survive in the competition. Measuring the satisfaction of consumer is a difficult job. But there are some ways these are as bellow.

While it seems clear that increasing customer satisfaction is beneficial to a marketing manager, how to measure it is less clear. Customer satisfaction has been studied from the perspective of the individual customer and what drives their satisfaction (Oliver and Swan 1989; Oliver 1993; Fournier and Mick 1999) as well as from an industry-wide perspective to compare customer satisfaction scores across firms and industries (Fornell 1992; Anderson, Fornell, and Lehmann 1994; Fornell et al. 1996; Mittal and Kamakura 2001), while other research has examined customer satisfaction in a single organization (Schlesinger and Zornitsky 1991; Hallowell 1996; Loveman 1998) or across several organizations (DeWulf, Odekerken-Schröder, and Iacobucci 2001).

In attempting to measure customer satisfaction, it is possible that attributes can have different satisfaction implications for different consumer and market segments the usage context, segment population, and market environment can influence satisfaction and product use (Anderson and Mittal 2000). Failure to take into account segment-specific variation may lead a firm to focus on the wrong aspect for a given set of consumers (Anderson and Mittal 2000). Furthermore, consumers with similar satisfaction ratings, yet different characteristics, may exhibit different levels of repurchase behavior (Mittal and Kamakura 2001). It is clear, then, that market and consumer segments should be important factors to consider when measuring customer satisfaction and its implications.

\subsection{Complaint and Suggestion System}

Now a day, complaint and suggestion system is treated as an effective mechanism of measuring customer level. Most of the companies are now establishing hot lines with toll free numbers. These are also practicing Web sites and e-mail for quick and both way communication. (Kotler,2004)

\subsection{Customer Satisfaction Surveys}

Responsive companies measure customer satisfaction directly by conducting periodic surveys. While conducting customer satisfaction data, it is also useful to ask additional questions to measure repurchase intension and to measure the likelihood or willingness to recommend the company and brand to others. (Kotler, 2004)

\subsection{Service Quality}

The primary responsibilities of employees in customer service positions usually entail creating and delivering the service in the customers' presence as well as providing information, taking instructions and receiving payments and solving problems. New customers in particular, often rely on customer service personnel for assistance in learning how to use a service effectively and how to resolve problems. For example, in the banking industry, the combination of a highly competitive and new technologies have forced banks to add more services in an attempt to increase their profitability(Bolton and Drew,1991).

During the 1980s and early 1990s, improving service quality has become a major priority. In a service context, this strategy required efforts to improve customer satisfaction by creating better service process and outcomes. Quality means different things to people according to the contest. Quality focuses on the benefits created for customers' side at the equation. (Bolton and Drew, 1991)

\subsection{Customer Queries}

Customer queries are an important feature of customer satisfaction. Different customers come to the bank with their different queries. They may have both the product and service related queries. Customers' queries indicate the customer's information search about the product and service of the bank. When a customer comes to the hank to search their information the staffs must have to he helpful and knowledgeable. When a customer comes to a bank he or she expects the best level of service from the employees. Employees won't be able to help these customers if they are not enough knowledgeable about the products and services they are providing. Customer queries in term of their account opening has to be efficient and employees' attention to be needed. When a customer opens a new account he or she has lots of queries about the hank as he/she is new in the bank. Customer has queries also in other area like their transaction with the bank. They have many queries about the transaction like the procedure, instruction, accuracy and efficiency. Customers have queries in terms of their 
complaints also. When they place a complaint they seek responsiveness, concern, expectations and arrangement. When a bank can efficiently provide the information of' customer queries, they will be able to make their customer highly satisfied. (Kotler, 2004)

\section{Analysis and Interpretation}

The survey regarding the customer satisfaction about the services provided by the BASIC Bank Limited, Khulna Branch has been conducted upon 200 customers of the branch. It is a questionnaire survey consisting of 27 statements under six broad categories. Respondents are asked to tick mark the best option considering their satisfaction of the particulars sectors. Statistical summary and interpretation are given below according to factors:

\subsection{First Factor: Products}

There are six types of products in BASIC Bank Khulna Branch. These are as follows

\subsubsection{Deposit Products Are Adequate To Meet the Need}

In each and every year BASIC Bank lunches new products as a response to the dynamic trends. In the present the bank has six types of deposits products with different features. And in very soon the branch added the credit card and on-line banking. The customers' satisfaction level towards "Deposit products are adequate to meet the need" is given below:

Table 3.1.1. Deposit products are adequate to meet the need

\begin{tabular}{|c|c|c|}
\hline Options & Value & Frequency \\
\hline Strongly Agree & 5 & 51 \\
\hline Agree & 4 & 143 \\
\hline Neutral & 3 & 5 \\
\hline Disagree & 2 & 1 \\
\hline Strongly Disagree & 1 & 0 \\
\hline Total & \multicolumn{2}{|c|}{200} \\
\hline Mean Score & \multicolumn{2}{|c|}{4.22} \\
\hline Standard Deviation & \multicolumn{2}{|c|}{0.252} \\
\hline
\end{tabular}

The BASIC Bank Limited, Khulna Branch provided six types of products to the customers, deposits products is one of them. From the table 51 respondents are strongly agree and 143 are agree out of 200 respondents in the case of deposits products are adequate to meet the need. The calculated mean value is 4.22 ; it indicates that the customers of the branch are satisfied from the service because the mean value is exits between value 5 and 4 . And the standard deviation is 0.252 , it mean that the customers' has lower variability; it is a good indicator because the higher value shows the grater variability.

\subsubsection{Varity of Services in Local Remittance is Satisfactory}

BASIC Bank limited local remittance services include TT (Telegraphic Transfer), DD (Demand Draft), PO (Payment Order) Collection and clearing. The banking processes here are the same as other banks. In this statement respondents are 190 out of 200 . Most of the respondents are satisfied as 70 respondents put tick on the option of "Strongly Agree". The customers' satisfaction level towards "Variety services in local remittance are satisfactory is given in next table:

Table 3.1.2. Varity of services in local remittance is satisfactory

\begin{tabular}{|c|c|c|}
\hline Options & Value & Frequency \\
\hline Strongly Agree & 5 & 70 \\
\hline Agree & 4 & 89 \\
\hline Neutral & 3 & 31 \\
\hline Disagree & 2 & 0 \\
\hline Strongly Disagree & 1 & 0 \\
\hline Total & \multicolumn{2}{|c|}{190} \\
\hline Mean Score & \multicolumn{2}{|c|}{4.21} \\
\hline Standard Deviation & \multicolumn{2}{|c|}{0.482} \\
\hline
\end{tabular}

From the table 4.1.2 it's seen that 190 no. of the surveyed customers had given their response the statement. 70 customers are strongly satisfied, 89 are satisfied and 31 are neutral out of 190 respondents in the case of local remittance services. The mean value is 4.21 that supports the customers are agree with the statement as the value assign to the option is 4 . The standard deviation 0.482 which denotes, there exist lower variability in the satisfaction of the customers.

\subsubsection{Loan Products (O/D, Term Loan) are Adequate to Meet the Need}

BASIC Bank Limited Khulna Branch offers five types of loans: Over Draft (OD), Term loan, Time loan, CCS (Consumer Credit Scheme) and LTR. But mainly provides the short term loan for their customers. To meet the customers' personal as well as business need the Bank should offer more products.

Table 3.1.3. Loan products $(O / D$, Term loan) are adequate to meet the need

\begin{tabular}{|c|c|c|}
\hline Options & Value & Frequency \\
\hline Strongly Agree & 5 & 25 \\
\hline Agree & 4 & 98 \\
\hline Neutral & 3 & 8 \\
\hline Disagree & 2 & 1 \\
\hline Strongly Disagree & 1 & 0 \\
\hline Total & \multicolumn{2}{|c|}{132} \\
\hline Mean Score & \multicolumn{2}{|c|}{4.11} \\
\hline Standard Deviation & \multicolumn{2}{|c|}{0.267} \\
\hline
\end{tabular}

Here mean score is 4.11 that mean the customers are satisfied with the statement as the value assigned between strongly satisfied and agree level. The standard deviation (0.267) suggests, the satisfaction of the respondents that has been given to the statement is consistent because the lower value is better in case of standard deviation.

3.1.4. Satisfied with different types of foreign exchange services

The foreign exchange department of BASIC Bank Ltd, Khulna Branch is mainly work two types one is opening $\mathrm{L} / \mathrm{C}$ 
and receives foreign remittance. Customers' satisfaction towards the "Satisfied with different types of foreign exchange services" is given below:

Table 3.1.4. Satisfied with different types of foreign exchange services

\begin{tabular}{lcc}
\hline Options & Value & Frequency \\
\hline Strongly Agree & 5 & 7 \\
Agree & 4 & 5 \\
Neutral & 3 & 1 \\
Disagree & 2 & 0 \\
Strongly Disagree & 1 & 0 \\
Total & & \\
Mean Score & $\mathbf{1 3}$ & \\
Standard Deviation & $\mathbf{4 . 4 6}$ & \\
\hline
\end{tabular}

From the table 4.1.4 it's seen that the 7 respondents are strongly satisfied and 5 are satisfied out of 13 respondents and no one is disagree by the services. The mean value is 4.46 indicates that the customers near strongly satisfied position. And the standard deviation is 0536 indicates the customers have moderate variability level.

\subsubsection{Locker Services is Satisfactory}

Customers' satisfaction towards the "Locker services is satisfactory" is given below:

Table 3.1.5. Locker services is satisfactory

\begin{tabular}{|c|c|c|}
\hline Options & Value & Frequency \\
\hline Strongly Agree & 5 & 4 \\
\hline Agree & 4 & 3 \\
\hline Neutral & 3 & 0 \\
\hline Disagree & 2 & 0 \\
\hline Strongly Disagree & 1 & 0 \\
\hline Total & \multicolumn{2}{|c|}{7} \\
\hline Mean Score & \multicolumn{2}{|c|}{4.57} \\
\hline Standard Deviation & \multicolumn{2}{|c|}{0.245} \\
\hline
\end{tabular}

The locker service by the BASIC Bank Khulna Branch is satisfactory, because the mean value is 4.57 . The customers of the bank are satisfied by the service. Mention that only 7 customers are surveyed out of 200 respondents. The standard deviation is 0.245 indicates that the customers are lower variability level.

\subsubsection{Purchase and Encashment of "Sanchaya Patra" is Satisfactory}

Different types of Sanchaya Patra are sold by the Bangladesh Bank through schedule banks.. The BASIC Bank Limited is one of them. Now the bank sells three types of Sanchaya Patra - 5Years Term Bangladesh Sanchaya Patra, 3months term Munaphaviitik Sanchaya Patra and 5 years Pensioner Sanchaya Patra. The rate of interest is $12 \%$, $11.50 \%$ and $12.50 \%$ respectively.
Table 3.1.6. Purchase and encashment of "Sanchaya Patra" is satisfactory

\begin{tabular}{|c|c|c|}
\hline Options & Value & Frequency \\
\hline Strongly Agree & 5 & 32 \\
\hline Agree & 4 & 4 \\
\hline Neutral & 3 & 0 \\
\hline Disagree & 2 & 0 \\
\hline Strongly Disagree & 1 & 0 \\
\hline Total & \multicolumn{2}{|c|}{36} \\
\hline Mean Score & \multicolumn{2}{|c|}{4.89} \\
\hline Standard Deviation & \multicolumn{2}{|c|}{0.099} \\
\hline
\end{tabular}

From the table 4.1.6 its seen that the 32 respondents are strongly satisfied out of 36 respondents and 4 is satisfied and no one is disagree by the services. The mean value is 4.89 indicates that the customers near strongly satisfied position. And the standard deviation is 0.099 (it is unique in this survey) indicates the customers had very lower variability level because the lower value shows that the customers opinions are not vary greatly.

\subsection{Second Factor: Rate of Interest}

\subsubsection{Interest Rate for Deposit and Schemes is High}

The following data are collected Bank Circular no 247/08 show the rate of interest which is effective March 01, 2008. The interest rate of savings deposits is $7.00 \%$. Mentioned that the rate is higher in any bank in Bangladesh in present time. The interest rate of STD is $4.50 \%$, FDR 3 months $7.25 \%$, 6 months $7.50 \%$ 1Year $8.00 \%$ and more than two years from $8.25 \%$ to $9.00 \%$.

Table 3.2.1. Interest rate for deposit and schemes is high

\begin{tabular}{|c|c|c|}
\hline Options & Value & Frequency \\
\hline Strongly Agree & 5 & 35 \\
\hline Agree & 4 & 143 \\
\hline Neutral & 3 & 2 \\
\hline Disagree & 2 & 0 \\
\hline Strongly Disagree & 1 & 0 \\
\hline Total & \multicolumn{2}{|c|}{180} \\
\hline Mean Score & \multicolumn{2}{|c|}{4.18} \\
\hline Standard Deviation & \multicolumn{2}{|c|}{0.172} \\
\hline
\end{tabular}

Here respondents' opinion varies to some extent, as standard deviation is 0.172 which indicates that the customers opinions are not vary one to another. Moreover, mostly voted opinion is (143) and means score is also 4.18 . So, customers are not fully satisfied.

\subsubsection{Interest Rate for Loan Product is Low}

Table 3.2.2. Interest rate for loan product is low

\begin{tabular}{|c|c|c|}
\hline Options & Value & Frequency \\
\hline Strongly Agree & 5 & 5 \\
\hline Agree & 4 & 32 \\
\hline Neutral & 3 & 78 \\
\hline Disagree & 2 & 21 \\
\hline Strongly Disagree & 1 & 0 \\
\hline Total1 & \multicolumn{2}{|c|}{36} \\
\hline Mean Score & \multicolumn{2}{|c|}{3.15} \\
\hline Standard Deviation & \multicolumn{2}{|c|}{0.513} \\
\hline
\end{tabular}


The customers of the BASIC Bank Limited response negatively at this statement as mean score is 3.15 which indicate that the customers are absolutely neutral in the position. The standard deviation is 0.513 indicates that the customers of the bank are moderately satisfied in the case of interest for loan product.

\subsection{Third Factor: Procedures of Services}

\subsubsection{Account Opening Procedure is Easy}

Account opening procedure of the bank is easy other specialization bank in Bangladesh. The difficulty is that the applicant has to show a valid photo ID, copy of TIN (Tax Identification Number), trade license and photo off nominee. But in present time account opening procedures is very lengthy and time consuming matter.

Table 3.3.1. Account opening procedure is easy

\begin{tabular}{|c|c|c|}
\hline Options & Value & Frequency \\
\hline Strongly Agree & 5 & 75 \\
\hline Agree & 4 & 122 \\
\hline Neutral & 3 & 1 \\
\hline Disagree & 2 & 2 \\
\hline Strongly Disagree & 1 & 0 \\
\hline Total & \multicolumn{2}{|c|}{200} \\
\hline Mean Score & \multicolumn{2}{|c|}{4.35} \\
\hline Standard Deviation & \multicolumn{2}{|c|}{0.298} \\
\hline
\end{tabular}

From the table 4.3.1, it is seen that among the 200 respondents, 75 of them are found strongly agree and 122 of them are also agreeing with the statement. Customers are very satisfied, as the mean score is 4.35 . They think, it is very important for financial institutions to know their customers very well. The dissatisfied customer's view that it is not always possible to arrange all when the applicant wants to open account immediately Standard deviation is 0.298 ; so views of customers are not consistent.

\subsubsection{TT, DD \& PO Issuing Procedure is Easy}

The BASIC Bank Limited provides service to the customers through TT, DD and PO as local remittance. The pay order is only the inter region service and TT and DD is national wide service.

Table 3.3.2. TT, DD \& $P O$ issuing procedure is easy

\begin{tabular}{|c|c|c|}
\hline Options & Value & Frequency \\
\hline Strongly Agree & 5 & 66 \\
\hline Agree & 4 & 93 \\
\hline Neutral & 3 & 35 \\
\hline Disagree & 2 & 0 \\
\hline Strongly Disagree & 1 & 0 \\
\hline Total & \multicolumn{2}{|c|}{194} \\
\hline Mean Score & \multicolumn{2}{|c|}{4.16} \\
\hline Standard Deviation & \multicolumn{2}{|c|}{0.495} \\
\hline
\end{tabular}

In the point of TT, DD and PO issuing procedure, 66 customers of the survey response strongly agree, 93 are agreed and no one is disagree and strongly disagree out of 194 respondents. The mean value 4.16 indicates that the customers are satisfied by the above service. It also indicates that the customer stay short time to get the service. The standard deviation is 0.495 indicates that the customers variation of the option is moderately satisfied.

\subsubsection{Loan Sanction and Disbursement System is Easy}

The BASIC Bank Ltd provides two types of loan one is working capital loan and another is term loan. Customers repay the loan equally monthly installment which is a strict law of the bank for the customers.

Table 3.3.3. Loan sanction and disbursement system is easy

\begin{tabular}{|c|c|c|}
\hline Options & Value & Frequency \\
\hline Strongly Agree & 5 & 19 \\
\hline Agree & 4 & 76 \\
\hline Neutral & 3 & 34 \\
\hline Disagree & 2 & 1 \\
\hline Strongly Disagree & 1 & 0 \\
\hline Total & \multicolumn{2}{|c|}{130} \\
\hline Mean Score & \multicolumn{2}{|c|}{3.87} \\
\hline Standard Deviation & \multicolumn{2}{|c|}{0.421} \\
\hline
\end{tabular}

The results shown in the table 3.3.3 identifies that customers are satisfied with this criterion. But some respondents are disagreed as they claim that the demanded more documents against the loan. The mean value 3.87 indicates that the customers are near satisfied level against the expectation. The standard deviation (0.421) also support that the customers are consistent.

\subsubsection{Cash Deposit and Withdrawal Procedure is very Quick}

Customers' satisfaction towards the "Cash deposit and withdrawal procedure is very quick" is given below:

Table 3.3.4. Cash deposit and withdrawal procedure is very quick

\begin{tabular}{|c|c|c|}
\hline Options & Value & Frequency \\
\hline Strongly Agree & 5 & 34 \\
\hline Agree & 4 & 144 \\
\hline Neutral & 3 & 22 \\
\hline Disagree & 2 & 0 \\
\hline Strongly Disagree & 1 & 0 \\
\hline Total & \multicolumn{2}{|c|}{200} \\
\hline Mean Score & \multicolumn{2}{|c|}{4.06} \\
\hline Standard Deviation & \multicolumn{2}{|c|}{0.277} \\
\hline
\end{tabular}

Cash deposit and withdrawal is a common picture of banking system. From the table 3.3.4 its seen that the 34 respondents are strongly satisfied and 144 are satisfied out of 200 respondents and no one is disagree by the services. The mean value is 4.06 indicates that the customers near strongly satisfied position. And the standard deviation is 0.277 indicates the customers had very lower variability level

\subsubsection{Queue System of Cash Counter is Perfect}

The customers need to know the balance of their account and it is known from the cash counter. Any customer can easily know through cell service or physically appearance by 
the both services. The table shows the results:

Table 3.3.5. Queue system of cash counter is perfect

\begin{tabular}{lcc}
\hline Options & Value & Frequency \\
\hline Strongly Agree & 5 & 45 \\
Agree & 4 & 130 \\
Neutral & 3 & 24 \\
Disagree & 2 & 1 \\
Strongly Disagree & 1 & 0 \\
Total & & $\mathbf{2 0 0}$ \\
Mean Score & $\mathbf{4 . 1 0}$ \\
Standard Deviation & & $\mathbf{0 . 3 5 6}$ \\
\hline
\end{tabular}

The cash counter of the bank is perfect, because 45 customers are strongly satisfied 130 are satisfied out of 200 respondents and no one is disagreed in the statement. The mean value is 4.10 indicates that the customers near strongly satisfied position. And the standard deviation is 0.356 indicates the customers had very lower variability level

\subsubsection{Customers' Complaint and Suggestion System is Satisfactory}

Before July, 2012 there is no customers' complaint box where the customers can write their complaint. Customers' satisfaction towards the "Customers' complaint and suggestion system is satisfactory" is given below:

Table 3.3.6. Customers' complaint and suggestion system is satisfactory

\begin{tabular}{|c|c|c|}
\hline Options & Value & Frequency \\
\hline Strongly Agree & 5 & 19 \\
\hline Agree & 4 & 50 \\
\hline Neutral & 3 & 127 \\
\hline Disagree & 2 & 4 \\
\hline Strongly Disagree & 1 & 0 \\
\hline Total & \multicolumn{2}{|c|}{200} \\
\hline Mean Score & \multicolumn{2}{|c|}{3.42} \\
\hline Standard Deviation & \multicolumn{2}{|c|}{0.474} \\
\hline
\end{tabular}

From the table 3.3.6 its seen that the 19 respondents are strongly satisfied, 50 are satisfied and 127 are neutral out of 200 respondents and no one is disagree by the services. The mean value is 3.42 indicates that the customers near strongly satisfied position. And the standard deviation is 0.474 indicates the customers had very lower variability level.

\subsection{Forth Factor: Charges}

\subsubsection{Account Related Charges is Low}

Account related charges include maintenance fee, average balance fee, transaction fee, counter transaction fee, account closing charge etc. Here 200 respondents give their opinions. BASIC Bank has a better position in relation to the topic of account related charges as the bank takes only what needs to maintain an account. Most customers give positive view as 23 respondents put tick on the option of "Strongly Agree".

Here is has been found that the 23 respondents are strongly satisfied, 140 are satisfied and 36 are neutral out of 200 respondents and no one is disagree by the services. The mean value is 3.93 indicates that the customers are near satisfied to a great extent. And the standard deviation is 0.325 indicates the customers had very lower variability level. So the customers opinions are vary one to another.

\subsubsection{Services Charge for Local Remittance is Low}

Services for local remittance are as usual in BASIC Bank Ltd and it doesn't vary with other banks. But some cases the bank provides lower charges for the customers.

The BASIC Bank Ltd. provides local remittance for their customers. And the charges of local remittance are lower than other private banks. From the survey, it is found that the 75 respondents are strongly satisfied, 78 are satisfied and 25 are neutral out of 200 respondents and no one is disagree by the services. The mean value is 4.09 indicates that the customers are satisfied to a great extent. And the standard deviation is 0.837 indicates the customers have very higher variability level. So the customers opinions are vary one to another.

\subsubsection{Satisfied with Charges for Foreign Exchange Services}

The foreign exchange department of the BASIC Bank (Khulna Branch) provides two types of services first one opening $\mathrm{L} / \mathrm{C}$ and second one is receive remittance.

From the survey, it is found that the 6 respondents are strongly satisfied and 10 are satisfied out of 200 respondents and no one is disagree by the services. The mean value is 4.05 indicates that the customers are satisfied to a great extent. And the standard deviation is 0.520 indicates the customers have moderate variability level. So the customers opinions are vary one to another.

\subsubsection{Loan Processing Fee is Reasonable}

Here is has been found that the perception towards the processing fee for the amount of loan is not so good. Here 133 respondents gave the response regarding the element. Among them 20 are neutral about the processing fee of BASIC Bank.. The mean score also supports this. The dissatisfied consumers also showed their logic behind their opinion. Firstly', they said that when they take the loan in a small size then sometimes the processing fee will be very high that's why even they go to other bank for small amount of loan. So the customers of BASIC Bank have a negative impression about the processing fee. Because customers said that service charge in order to maintain account is very high so processing charge for loan is an extra burden.

\subsubsection{Charges for TT, DD, PO is Reasonable}

The service charge of TT, DD and PO is lower than other bank in the city. The services charges are vary in some special cases. In the case of TT (TK. 1.00 lac to 5.00 lac) charge is commission tk.50, telegraphic charge tk.50 and VAT Tk 8 and more than 5.00 lac charge will be increased by $0.1 \%$ and telegraphic charge will be fixed.

From the survey, it is found that the perception towards charge for Pay Order TT and DD is good. Here among the 33 respondents are strongly satisfied and 140 are satisfied about the charges of BASIC Bank Ltd when they were asked 
whether the charge for Pay Order TT, DD is reasonable. On the other side there is no consumer can be found that they are strongly agreed about the charge for Pay Order, TT, and DD of the bank. The mean value is 4.05 indicates that customer of the bank are satisfied by the service. The standard deviation 0.283 implies that the customers of the bank are lower variability.

\subsection{Fifth Factor: Performance of Employees}

\subsubsection{Employees Skill and Knowledge is Satisfactory}

Employee's skill and knowledge are essential to best customers' service. The well trained employees provides good services in any point. From the survey, it's seen that the 17 respondents are strongly satisfied and 175 are satisfied out of 200 respondents and no one is disagree by the services. The mean value is 4.05 indicates that the customers are satisfied to a great extent. And the standard deviation is 0.623 also support the interpretation. Employees' skill and knowledge is satisfactory.

\subsubsection{Employees are Friendly and Respectful to Solve the Customer Problems}

It is important work of the employee to solve the customers' problems. And the employee should solve the problem friendly and respectfully.

It has been found that the 76 respondents are strongly satisfied and 114 are satisfied out of 200 respondents and no one is disagree by the services. The mean value is 4.33 indicates that the customers are satisfied to a great extent. And the standard deviation is 0.321 indicates the customers have lower variability level. So the customers opinions are vary one to another. Employees are friendly and respectful to solve the customer problems

\subsubsection{Employees are Trustworthy}

Customers' satisfaction towards the "Employees are trustworthy" is given below:

Table 3.5.3. Employees are trustworthy

\begin{tabular}{|c|c|c|}
\hline Options & Value & Frequency \\
\hline Strongly Agree & 5 & 41 \\
\hline Agree & 4 & 100 \\
\hline Neutral & 3 & 57 \\
\hline Disagree & 2 & 2 \\
\hline Strongly Disagree & 1 & 0 \\
\hline Total & \multicolumn{2}{|c|}{200} \\
\hline Mean Score & \multicolumn{2}{|c|}{3.90} \\
\hline Standard Deviation & \multicolumn{2}{|c|}{0.520} \\
\hline
\end{tabular}

The table 3.5.3 its seen that the 41 respondents are strongly satisfied and 100 are satisfied out of 200 respondents and no one is disagree by the services. The mean value is 4.33 indicates that the customers are satisfied to a great extent. And the standard deviation is 0.520 indicates the customers have moderate variability level.

\subsubsection{Employees Perform the Services with Consistency and Accurately}

Customers' satisfaction towards the "Employees perform the services with consistency and accurately" is given below

Table 3.5.4. Employees perform the services with consistency and accurately

\begin{tabular}{lccc}
\hline Options & Value & Frequency \\
\hline Strongly Agree & 5 & & 57 \\
Agree & 4 & & 100 \\
Neutral & 3 & & 34 \\
Disagree & 2 & & 9 \\
Strongly Disagree & 1 & & 0 \\
Total & & $\mathbf{2 0 0}$ & \\
Mean Score & & $\mathbf{4 . 0 3}$ & \\
Standard Deviation & & $\mathbf{0 . 6 3 4}$ & \\
\hline
\end{tabular}

The above table 4.5.4 its seen that the 57 respondents are strongly satisfied and 100 are satisfied out of 200 respondents and no one is disagree by the services. The mean value is 4.03 indicates that the customers are satisfied. And the standard deviation is 0.634 indicates the customers have lower variability level. So the customers opinions are vary one to another.

\subsubsection{Employees Respond Quickly to Customer Request and Problems}

It has been found that the 59 respondents are strongly satisfied and 93 are satisfied out of 200 respondents and no one is disagree by the services. The mean value is 4.04 indicates that the customers are satisfied to a great extent. And the standard deviation is 0.594 indicates the customers have moderate variability level. So we can say that employees respond quickly to customer request and problems.

\subsubsection{Top Level Employee Support is Satisfactory}

From the survey, it has been found that the 70 respondents are strongly satisfied and 120are satisfied out of 200 respondents and no one is disagree by the services. The mean value is 4.30 indicates that the customers are satisfied to a great extent. And the standard deviation is 0.310 indicates the customers have lower variability level. So we can say that the top level employee support is satisfactory.

\subsection{Sixth Factor: Physical Environment and Support}

\subsubsection{Bank Location is Convenient}

Customers' satisfaction towards the "Bank Location is Convenient" is shown below:

Table 3.6.1. Bank Location is Convenient

\begin{tabular}{|c|c|c|}
\hline Options & Value & Frequency \\
\hline Strongly Agree & 5 & 4 \\
\hline Agree & 4 & 122 \\
\hline Neutral & 3 & 73 \\
\hline Disagree & 2 & 1 \\
\hline Strongly Disagree & 1 & 0 \\
\hline Total & \multicolumn{2}{|c|}{200} \\
\hline Mean Score & \multicolumn{2}{|c|}{3.65} \\
\hline Standard Deviation & \multicolumn{2}{|c|}{0.279} \\
\hline
\end{tabular}


From the table 3.6.1 it's seen that the 4 respondents are strongly satisfied and 122 are satisfied out of 200 respondents and no one is disagree by the services. The mean value is 3.65 indicates that the customers near satisfied position. And the standard deviation is 0.279 indicates the customers had very lower variability level.

\subsubsection{Internal Environment is Suitable}

Bank's internal environment means its interior decoration, lighting, ventilation, air conditioner etc. BASIC Bank internal environment is suitable to its consumer.

Here the responses given by the customers are strongly agree, agree, neutral and disagree. The respondents appreciated about the decoration of the bank, but the most strong point of view for BASIC Bank Ltd. Khulna branch is that there is no customer who said that they have a negative impression about the banks internal environment. But few consumers were talking about the space of the bank they think that the bank space is not sufficient. The mean value is 3.55 indicates that customers of the bank is near satisfaction level and the standard deviation (0.328) also support the results.

\subsection{Statistics on Survey}

Table 3.7. Survey results at a glance

\begin{tabular}{|c|c|c|c|}
\hline Factors & Mean Score & $\begin{array}{l}\text { Standard } \\
\text { Deviation }\end{array}$ & $\begin{array}{l}\text { Valid } \\
\mathbf{N}\end{array}$ \\
\hline \multicolumn{4}{|l|}{ A. Products } \\
\hline 01. Deposit products are adequate to meet the need & 4.22 & 0.252 & 200 \\
\hline 02. Varity of services in local remittance is satisfactory & 4.21 & 0.482 & 190 \\
\hline 03. Loan products $(\mathrm{O} / \mathrm{D}$, Term loan) are adequate to meet the need & 4.11 & 0.267 & 132 \\
\hline 04. Satisfied with different types of foreign exchange services (Import L/C) & 4.46 & 0.536 & 13 \\
\hline 05 . Locker services is satisfactory & 4.57 & 0.245 & 7 \\
\hline 06. Purchase and encashment of "Sanchaya Patra" is satisfactory & 4.89 & 0.099 & 36 \\
\hline Average & 4.41 & 0.314 & \\
\hline \multicolumn{4}{|l|}{ B. Rate of Interest } \\
\hline 07. Interest rate for deposit and schemes is high & 4.18 & 0.172 & 180 \\
\hline 08. Interest rate for loan product is low & 3.15 & 0.513 & 136 \\
\hline Average & 3.67 & 0.343 & \\
\hline \multicolumn{4}{|l|}{ C. Procedures pf Services } \\
\hline 09 . Account opening procedure is easy & 4.35 & 0.298 & 200 \\
\hline 10. TT,DD \& PO issuing procedure is easy & 4.16 & 0.495 & 194 \\
\hline 11. Loan sanction and disbursement system is easy & 3.87 & 0.421 & 130 \\
\hline 12. Cash deposit and withdrawal procedure is very quick & 4.06 & 0.277 & 200 \\
\hline 13. Queue system of cash counter is perfect & 4.10 & 0.356 & 200 \\
\hline 14. Customers' complaint and suggestion system is satisfactory & 3.42 & 0.474 & 200 \\
\hline Average & 3.99 & 0.387 & \\
\hline \multicolumn{4}{|l|}{ D. Charges } \\
\hline 15. Account related charges (maintenance fee, average balance fee, inter-city charge ) is low & 3.93 & 0.325 & 200 \\
\hline 16. Services charge for local remittance is low & 4.09 & 0.837 & 194 \\
\hline 17. Satisfied with charges for foreign exchange services & 4.05 & 0.520 & 21 \\
\hline 18. Loan processing fee is reasonable & 3.87 & 0.228 & 133 \\
\hline 19. Charges for TT,DD,PO is reasonable & 4.05 & 0.283 & 196 \\
\hline Average & 4.00 & 0.439 & \\
\hline \multicolumn{4}{|l|}{ E. Performance of the Employee } \\
\hline 20. Employees skill and knowledge is satisfactory & 4.05 & 0.623 & 200 \\
\hline 21. Employees are friendly and respectful to solve the customer problems & 4.33 & 0.321 & 200 \\
\hline 22. Employees are trustworthy & 3.90 & 0.520 & 200 \\
\hline 23. Employees perform the services with consistency and accurately & 4.03 & 0.634 & 200 \\
\hline 24 Employees respond quickly to customer request and problems & 4.04 & 0.594 & 200 \\
\hline 25. Top level employee support is satisfactory & 4.30 & 0.310 & 200 \\
\hline Average & 4.11 & 0.500 & \\
\hline \multicolumn{4}{|l|}{ F. Physical Environment and Support } \\
\hline 26. Bank Location is Convenient & 3.65 & 0.279 & 200 \\
\hline 27. Internal environment (decoration, ease of contact, lighting, cleanliness) is suitable & 3.55 & 0.328 & 200 \\
\hline Average & 3.60 & 0.304 & \\
\hline
\end{tabular}

Table 3.7 summarizes the survey result of the satisfaction of the customers about service provided by the BASIC Bank. Khulna, The average score suggests, among the 6 main factors the product offering, charges and performance of the employees' satisfied customers. And the customers are not fully satisfied by the rate of interest and physical 
environment and support. In case of procedure of service the average mean score is 4.38 that mean they are not fully satisfied by the overall procedure of the service. The standard deviation of the satisfied factors are less than the standard deviation of the dissatisfied factors that means, there exits less variability in the opinion on the satisfied factors.

As the factors are consisted of 27 statements, variability in opinion on some of the statements influences the average mean score of a particular factor. In case of procedure of service which consists of 6 statements, the customers are satisfied by the account opening requirements, queue system of the cash counter and number of installment hut they are dissatisfied by the documents required for loan approval and the action that the bank take for failing the loan installment. So the average mean score suggests that the customers are not fully satisfied by the procedure of the service.

Among the six factors it seen that the average mean value 4.41 and standard deviation is 0.314 in case of products. In the second, factors the average mean score is 3.67 and average standard deviation is 0.343 indicates that the customers are not satisfied in case of rate of interest. In case of procedures of services the average mean value is 3.99 and average standard deviation is 0.387 indicates that the customers are near satisfactory level. The four factors the average mean value is 4.00 and average standard deviation is 0.439 indicates that the customers are satisfactory level. In the point of performance of the employees average mean value is 4.11 and average standard deviation is 0.500 indicates that the customers are moderate satisfactory level. In the last point of physical environment average mean value is 3.60 and average standard deviation is 0.304 indicates that the customers are moderate satisfactory level. From the above discussion it is concluded that the customers are more satisfied in the first factor and lower satisfied in the last point.

\section{Findings}

After analysis the survey results of BASIC Bank Ltd., Khulna Branch have found different types of value and it indicates different meaning. The general findings are as follows:

\subsection{Products}

- In the case of products customers are satisfied and the variability level is moderate (Table 3.7). It also found that, deposit products are not adequate to meet the need as mean value is 4.22.Loan products are not adequate to meet the customers need and mentioned that there is no long term loan facility.

- In the point of occupation level service holders are more satisfied than business persons but not very difference.

- In the point of income level lower income groups are more satisfied than other groups and it average mean value is 4.50 , then income groups (TK. 40000-80000) is 4.40 and finally higher income groups are 4.21

\subsection{Rate of Interest}

- In the case of interest the customers of the bank are not satisfied if the variability is lower level (Table 3.7). It also found that interest for loan products are higher than customers' expectation as mean value 3.15 . The rate is vary $10.00 \%-14.75 \%$.

- In the point of occupation groups average mean value shows that both are not satisfied.(Table 3.9.2)

- In the case of income level the both groups are near same position. But lower income groups have great variability than other groups.

\subsection{Procedures of Services}

- In the case of procedures of services the customers of the bank are near satisfaction level i.e. the average mean value is near the value 4 (Table 3.7). In the case of cash deposit and withdrawal procedure the customers are not fully satisfied. And the customers' compliant and suggestion are not good as mean value 3.42 (Table 3.3.6)

- In the point of occupation both business and service holders are near same position. They are stayed the same level of point.

- On the other part of analysis it is seen that higher income groups are more satisfied than other groups

\subsection{Charges}

- In the point of charges the customers are exist satisfaction level (Average mean value 4.00 (Table 3.7). In case of service charges for local charges are not reasonable in some cases as mean value 4.05 (Table 3.4.5). And in the case of loan processing the customers are not satisfied as mean value 3.87 and it higher than customers' expectation. Charges for foreign charges $\mathrm{L} / \mathrm{C}$ (Letter of Credit) is more than other private banks as mean value is 4.05 (Table 3.4.3)

- In the case of occupation, the businesses are more satisfied than that of services holders. (Average mean value of business is 4.04 and services holders is 3.98). But the business exist more variability than service holders.

- In the income level, higher income groups are more satisfied than other income groups. But the variability level is more than others.

\subsection{Performance of the Employees}

- The factors performance of the employees seen that the customers are satisfaction level as average value 4.11. It also seen that it has moderate variability (Table 3.7).It found that the customers' complaints and suggestion system are not satisfactory because the mean value is 3.42 (Table 3.3.6)

- In occupation level the service holders are more satisfied than businesses. But service holders have 
greater variability.

- In the groups are more satisfied than others two groups. But the average standard deviation of second income groups (TK.40000-80000) is higher i.e. it exist higher variability.

\subsection{Physical Environment and Support}

- The customers of the bank are not fully satisfied as average value 3.60. But the variability level of the customers is lower than other factors. (Table 3.7)

- In the case of occupation the service holders are more satisfied than business but not satisfactory level. And the factors exists lower variability level.

\section{Conclusion}

The BASIC Bank Ltd, Khulna Branch is performing better to its customer's services through its services products. It is found from the study that the responses of the customers on the performance of BASIC Bank Ltd. Khulna are quite well. At the time of survey, some clients of BASIC Bank, Khulna branch highly appreciate some features of this bank but they also show their negative attitude about some criteria Among the identified six factors, customers have positive views towards every of the factors. They are neutral in some factors especially in the physical environment and support. And customers are not found strongly dissatisfied in any statements out of 27 .

It is apparent from the survey that the customers are satisfied with quick service delivery process, some charges as well as satisfactory procedure of services. The bank's service charge is low also. Customers possess overall good attitude about foreign and local remittance services. But depositary and loan products are not adequate for them. Customers are dissatisfied with interest rate of loan. Moreover they' are satisfied with account Opening requirements, One-stop services of cash counter and loan adjustment procedure. Among the physical environment and support, customers are satisfied through location of the bank.

The study also reveals that the customers are satisfied by the overall performance of BASIC Bank, Khulna branch that is why most of them are interested to take further financial services from bank. They express most positively that they will refer also to others to take services from this bank. And bank officials also inform that some of the customers are good source of referral.

From the analysis of variation due to demographic difference it is found that both business and service holders are satisfied but some cases are different. And in the income level higher income groups (TK.80000+) are more satisfied in some cases but not all. The savings account holders are highly satisfied in case of purchase and encashment of different types of "Sanchaya Patra".

During first half of FY08, exports, import payments and remittances receipts increased by 4.43 percent to US\$6495.92 million, 15.90 percent to US\$9599.80 million and 26.24 percent to US\$ 4827.31 million against US\$ 6220.61 million, US\$ 8282.50 million, and US\$ 3824.04 million respectively during the same period of the previous year. Total official foreign aid disbursement increased by 3.6 percent to USD 1625.0 million in FY(Fiscal Year) 07 from USD 1568.0 million received in FY06. Development outlook in FY08 the growth of the Bangladesh economy is expected to slow down in 2008 due to a series of natural calamities including two rounds of floods and the cyclone Sidr, which never happened in one year in recent past. Some 46 out of the country's 64 districts were adversely affected with more than 16million people marooned and over 2 million houses damaged in the floods, the worst since 1998.

Finally the BASIC Bank Ltd is a renowned in Bangladesh in especially small business sectors. If the banks initiative to overcome negative barriers which are viewed by customers, the services would be more attractive and competitive this will be benefit both customers and the bank.

\section{References}

[1] Almossawi M (2001). Bank selection criteria employed by college students in Bahrain: an empirical analysis. Int. J. Bank. Mark. 19(3): 115-125.

[2] Anderson, Eugene W., Claes Fornell, and Donald R. Lehmann (1994), "Customer Satisfaction, Market Share, and Profitability: Findings from Sweden," Journal of Marketing, 58 (3), 53-66.

[3] Anderson, E.W., and Fornell, C. (1994).“A customer satisfaction research prospectus" In R. Rust and R.J. Oliver (Eds.), Service quality: New direction in theory and practice (pp. 241-268). Thousand Oaks: Sage.

[4] Benito E (2008). Size, growth and banks Dynamics, Banco de Espana Working p. 0801.

[5] Berry, L.(1984) "Service marketing is different, " in Lovelock, C.(Ed), Service Marketing, Englewood Cliffs, NJ

[6] Bitner, M. J., "The service encounter, diagnosing favorable and unfavorable incidents" Journal of Marketing, Vol. 54, 1990

[7] Bolton, R.N. and Drew, J. H., (1991), "Journal of Service Marketing", Vol. 11, 2002.

[8] Bolton, Ruth N. (1998), “A Dynamic Model of the Duration of Customer's Relationship with A Continuous Service Provider: The Role of Satisfaction," Marketing Science, 17 (1), 45-65.

[9] Chang YH, Yeh, CH (2002). A survey analysis of service quality for domestic airlines. Eur. J. Oper. Res. 139 (2002): 166-177.

[10] Colgate, M., Stewart, K and Kinsella,(1996). Customer Defection: A Study of the Student Market in Ireland. The International Journal of Bank Marketing, 14(3)

[11] Drucker, Peter F. (1954), The Practice of Management, New York: Harper \& Row. 
[12] Fornell, C., "A National Customer Satisfaction Barometer: The Swedish Experience". Journal of Marketing, Vol. 56 (January), 1992, 6-21.

[13] Fournier, S. and Mick, D.G. (1999), "Rediscovering satisfaction", Journal of Marketing, Vol. 63, October, pp. $5-23$.

[14] Gilbert GR, Veloutsou C (2006)."A cross-industry comparison of customer satisfaction", The Journal of Services Mark. 20(5): 298-308.

[15] Gupta S.P. and Gupta M.P. (2006), $11^{\text {th }}$ edition, Sultan Chand \& Sons, New Delhi

[16] Hallowell, Roger (1996), "The Relationships of Customer Satisfaction, Customer Loyalty, and Profitability: An Empirical Study," International Journal of Service Industry Management, 7 (4), 27-42.

[17] Harvey (2010). Banking Reform in Ethiopia, Institute Of Development Studies, IDA Working p. 37.

[18] Hazlina (2011). Impacts of service quality on customer satisfaction: Study of Online banking and ATM services in Malaysia, Int. J. Trade. Econ. Fin. 2(1).

[19] He Y, Song H (2009). A Mediation Model of Tourists' Reprchase Intentions for Packaged Tour Services, J. Travel. Res. 47(3): $317-31$.

[20] Innis, Daniel E "Customer service: The key to customer satisfaction, customer loyalty, and market share". Journal of Business Logistics.1994.

[21] Kellar, G. M. and M. W. Preis, "Modeling Increased Repurchase Intentions in High-Tech B2B Markets Using Information Theoretic Approach". Academy of Marketing Studies Journal, 2003

[22] Kauffman. R. G., "Influences on Industrial Buyers' Choice of Products: Effects of Product Application, Product Type, and Buying Environment". International Journal of Purchasing and Materials Management, (Spring). 1994.

[23] Kotler P, Armstrong G (2012). Principles of Marketing, 14 th Edition, New Jersy, USA . Pearson Education Inc.

[24] Lovelock, C, Services Marketing (2001), Fourth Edition, Pearson Education (Singapore) Pvt. Ltd. Indian Branch, New Delhi

[25] Lovelock, C. "An integrated approach to service management," Service Marketing, $4^{\text {th }}$ edition Pearson Education (Singgpore) Pvt. Ltd., Delhi,pp15-17
[26] Levitt, T., "Marketing Intangible Products and products Intangible" Harvard Business Review, pp 41-52.

[27] Michael W. Preis "A information theoretic approach to modeling customer satisfaction for low-tech industrial offering" Journal of the Academy of Business and Economies Feb.2003.

[28] Mittal, V., J.M. Katrichis and P. Kumar, "Attribute Performance and Customer Satisfaction Over Time: Evidence From Two Field Studies". The Journal of Services Marketing, Vol. 15(4/5), 2001

[29] Malhotra, Naresh K. (2006), Marketing Research: An Applied Orientation, $4^{\text {th }}$ edition, Pearson Education, Singapore.

[30] Oliver, Richard L. (1993), "Cognitive, Affective, and Attribute Bases of the Satisfaction Response," Journal of Consumer Research, 20 (3), 418-430.

[31] Ravichandran K (2010). Influence of Service Quality on Customer Satisfaction, Application of SERVQUAL Model, Int. J. Bus. Manage. 5: 117-124.

[32] Reidenbach, R.E. (1995). Value-Driven Bank: Strategies for Total Market Satisfaction. Irwin Professional, U.K.

[33] Sulieman (2011) Banking Service Quality Provided by Commercial Banks and Customer Satisfaction, American Journal of Scientific Research, ISSN 1450-223X Issue 27(2011), pp. 68-83

[34] Sureshchandra, G.S., Rajendran, C., and Ananthoraman, R.N., "Journal of Service Marketing", Vol. 33, 2002.

[35] Tee (2012). The Effects of Service Quality, Customer Satisfaction on Re-patronage Intentions of Hotel Existing Customers, Int. J. Manage. Administr. Sci. 1(8).

[36] Yi, Y., "A Critical Review of Customer Satisfaction.” In V.A. Zithmal(Ed), Review of Marketing 1990.

[37] Zahoor (2011) SERPERF Analysis in the Banking Services, Unpublished Master theses, Karachi Institute of Economics and Technology

[38] Zeithmal, V., Service Marketing, Third Edition, Tata McGraw- Hill Publishing Company Limited, 7 West Patel Nagar , New Delhi http://www.basicbanklimited.com 